\title{
Rechtsgeschichte
}

\section{Simeon Evstatiev}

\section{Comprehensive Secularity}




\section{Comprehensive Secularity*}

Demand for books about secularism in modern Turkey, its distinctive ideology and social practices as seen in their interplay with Islamic movements grew as a result of the specific situation in this country due to the democratic process and the increasing visibility of Muslim actors in the public and political life as against the backdrop of transnational developments such as the globally significant II September 200I attacks on the United States. The book by Yllmaz Bulut Laizismus oder übergreifende Säkularität des Rechtstaates. Der Diskurs um den Laizismus in der Türkei - a revised version of a doctoral dissertation prepared at the University of Frankfurt/Main - is among the most recent works that seek to face an important challenge. Bulut is not only suggesting a fresh analysis of laicism, but is heuristically proposing a theoretical solution to the often conflictual interactions between the radically secularizing Kemalist élite and the religiously motivated social forces. Taking up on one of the most debated issues in Turkey today, highly relevant to both the domestic socio-cultural developments and the country's transnational role, the author frames it in a manner that merits attention.

Bulut outlines the need for new social conditions with the potential to create a consensussupportive development perspective against the backdrop of the tension line between democratization processes and the laicism expectations of the state. Instead of looking for imagined deficiencies of an ressentialized Islam or asking what its alleged >compatibility $<$ or >non-compatibility< with secular democracy may look like (cf. I8I-I82), the author emphasizes the discourse on laicism itself. This approach has two specific benefits: first, it allows Bulut to consistently develop the hypothesis at the core of his work - that the liberal discourse around the contested concept >laicism < could foster the formation of a democratic consensus, and that the shaping of a >comprehensive secularity< (übergreifende Säkularität) of the rule of law (Rechtsstaat) is viable under its scaffolding. In doing so, the author draws heavily on John Rawls's political philosophy (2I) to argue that the possibility of a higher democratic functionality of the secular principles in Turkey is interrelated with the realization of an >overlapping consensus` (übergreifender Konsens) (8). The pursuit of this task, according to the author, requires a re-formulation of the concept of laicism towards a replacement of the >militant laicism` with a >comprehensive secularity<. Second, through this approach Bulut examines the major socio-political groups through the three key discourses under study the Kemalist discourse, the liberal discourse, and the >Islamic subject-position in relation to laicism - through a focused discourse analysis combined with methods from the sociology of knowledge that may lead to a new reconstruction of the political processes in terms of interpretive sociology. The author proposes a sociocultural contextualization of the analyzed discourses which is a very promising approach, although some of its aspects remain insufficiently clear - for example, what the author exactly means by »involving also personal observations in the country " (II) seems vague.

In devising the structure of his book Bulut adheres to the conventions of the genre and logically unfolds it into three main chapters framed by a solid introduction that meets the

\footnotetext{
Yilmaz Bulut, Laizismus oder übergreifende Säkularität des Rechtstaates? Der Diskurs um den Laizismus in der Türkei (Schriftenreihe von Stipendiatinnen und Stipendiaten der Friedrich-EbertStiftung 34), Berlin [u. a.]: Lit 2008, 219 S., ISBN 978-3-8258-I I 78-5
} 
highest professional standards of academic scholarship and a larger concluding chapter summing up the major results of the study, including a smeta-reflection aims at laying the methodological and conceptual ground for further discourse analysis. Starting with ssecularization $<$ the author explains his main concepts underlying the key term übergreifende Säkularität. Although Bulut does not offer an in-depth discussion of major recent and current debates within religious studies, and particularly the study of Islam, he argues that modernizing tendencies can also be vested in religion itself « (г 8). The suggested methodological basis of the work is theoretically substantiated by explaining how exactly the chosen discourses are analyzed as well as by offering a satisfactory argumentation of the selection criteria regarding the >discourse documents as well as the rthematic fields.

The second chapter sets up the core part of the analysis in which the author discusses the chosen discourses as text phenomena and the result of the social practice. By drawing on insights by Şerif Mardin and Edward Shils the author adopts the dichotomy scenter-periphery to demonstrate the traits of the top-down processes characteristic for post-Ottoman Turkish society and the more recent changes occurring in Turkish spolitical culture (a term the scope of which remains insufficiently specified in the book) as a result of the democratization since the last decades of the twentieth century. The suggested approach, which may be defined as a contextualized discourse analysis, is an intriguing one for scholars from different disciplines. It is unfortunate that the analysis presented in this chapter falls far short from its promise. A part of the problem is the lacking type of account of what people actually do in a specific, direct relation to their public discourses. What Bulut provides in this section of his analysis is a frequently schematic and fragmentary historical survey of Kemalist, liberal and Islamic groups in the modern Turkish Republic. Some assertions such as »the tradition of folk Islam and its holders form the core of the first civil society structures « (66) are insufficiently justified. Indeed, such social phenomena as ifolk Islam could be analyzed in terms of the rgenealogy of the public sphere (in the sense of Armando Salvatore) but naming them >civil society< needs further justification. Very free< use of terms and concepts as applied to Islamic movements can also be found in the book, for example, in the discussion of the Nurcu movement defined by the author as a sect in Islam - a statement that, if applicable at all, would need further explanation.

Another problematic issue is the otherwise original attempt to consistently view the Islamic movements through the eyes of the liberal discourse - an approach which would have had a higher theoretical potential without its implicit suggestion that it is the liberal discourse which could a absorb the Islamic one through the public realm. Despite that it is presented as a much ssoftened version of the Kemalism, the liberal discourse still remains deeply rooted in the notion of a monolithic Westernizing notion of modernity - a trajectory of thought that the author himself claims to reject. If Muslim movements are increasingly on the public and political stage, then why should we analyze them only through their relations to an allegedly comprehensive lliberal discourse ? What is the concrete relationship in situ between the two radically different types of discourses - the liberal and the Islamic? What does the acceptance of laicism by Islamic actors in the public domain actually mean to the 
actors themselves, to their religiosity and political participation? These questions remain unanswered, although the historical surveys in that chapter are useful for a reader unfamiliar with the political developments in modern Turkey.

The third chapter discusses the discourse contents and the major discourse holders as identified by Bulut. This is the most innovative part of the book which, drawing on earlier research and primary sources and discourse documents in Turkish language, marks a scholarly advance demonstrating the main results of the author's original research. Significantly, Bulut is very consistent and relates the main elements of his analysis with his research questions, hypotheses and methods. The reader gets a picture of assiduously classified Kemalist and liberal discourses as well as Islamic discourse positions. The analysis of the demonstrated readiness of the Islamic groups to cooperate with the liberals (I 50 ) leads to some of the major conclusions and recommendations by Bulut. It is not by accident that he has enlarged his conclusion turning it into an integral, additional fourth chapter of the work dedicated to the results of the work.

Among the core results of the book is the suggested new definition of laicism - a new secularity of the rule of law should not be rooted in ideology as Kemalist laicism is, and should provide a method for achieving social harmony. Legislation and administrative practice should abandon the anti-religious line and offer practical solutions that correspond to the social and religious needs within society. The idea, which is at the core of the entire book, is considered justified - the liberal position represents a mediation and arbitration instance between the two antagonistic positions: the Islamic and the Kemalist. Appealing for an open dialogue with the Islamic representatives in terms of sfree democracy<, Bulut believes that »the questions of democracy could become a task of religion « (I78I79), and that »the prerequisites for a radical Islamism are lacking until now « as »moderate Muslims form the majority of Turkey's believers today « ( I 86). Thus, opening the floor for further discussions, Bulut sees the solution in the liberal discourse which differs from the Kemalist with its being non-institutionalized. For him, the liberal discourse is therefore, a sort of a »third way « which can serve as the basis for the future of Turkey (I94).

In sum, the monograph of Yilmaz Bulut represents a normative oriented discourse analysis highly relevant to three major socially significant groups in contemporary Turkey - the Kemalists, the liberals and the Islamic actors in the public and political domains. Despite the shortcomings pointed above, this is in general a successful work on a vital issue with both academic and policy relevance not only for Turkey but for Europe as a whole. A more cautious and historically informed involvement of the Islamic actors as seen vis-à-vis the liberal and Kemalist ones would have been a welcomed opportunity for the author to prove his theses by seeking to achieve a more specific socio-cultural contextualization of the analyzed discourses. Nevertheless, the book's brevity, theoretical soundness and heuristic potential makes it an important reading as part of the contemporary debates on the public role of religion, and particularly Islam, in Turkey and elsewhere.

Simeon Evstatiev 